УДК 574.5 (28): 592

\title{
ОЗЕРНЫЕ ГОЛЬЦЫ (SALVELINUS, SALMONIDAE) МАТЕРИКОВОГО ПОБЕРЕЖЬЯ ОХОТСКОГО МОРЯ
}

\author{
Волобуев В. В., Грушинец А. В. \\ ФГБНУ Магаданский научно-исследовательский институт рыбного хозяйства и океанографии, \\ 2. Магадан \\ E-mail:volobuev@magadanniro.ru
}

\begin{abstract}
Приведены сведения о распространении, миграциях, размножении, питании, возрасте и росте популяций жилых гольцов из озер материкового побережья Охотского моря. Дана морфобиологическая характеристика двух форм озерного гольца-нейвы: быстрорастущей и карликовой. Представлены сведения о популяциях озерных гольцов из других водоемов.
\end{abstract}

Ключевые слова: распространение, миграции, питание, возраст и рост, озерные гольцы.

DOI: $10.34078 / 1814-0998-2020-2-69-85$

\section{ВВЕДЕНИЕ}

Озерные гольцы р. Salvelinus распространены циркумполярно в Северном полушарии. Они встречаются в Азии, Европе, Северной Америке; в Гренландии, Исландии, Великобритании и на других арктических островах и представлены как симпатрично с проходным гольцом, так и изолированными популяциями (DeLacy, Morton, 1943; Perch, 1958; Лобовикова, 1959; Савваитова, 1961, 1973, 1989; Мина, 1962; Quegley, 1962; Frost, 1965; Nilsson, 1965; Gullestad, 1973; и др.).

По материковому побережью Охотского моря озерные гольцы, проводящие весь жизненный цикл в озерах, обитают в бассейнах рр. Вилига, Ола, Яма, Охота, Иня и др. (Волобуев, 1976а, 1977, 1978; Волобуев, Рогатных, 1998). Из опросных сведений и литературных источников следует, что в многочисленных озерах побережья существуют и другие популяции гольца. Так, имеются данные о гольце из Элекчанских озер, расположенных в верховье р. Яма (Гудков, Радченко, 2000). Авторы приводят сведения о его морфобиологических показателях, темпе роста, окраске, генетической структуре. Обсуждаются вопросы филогении элекчанского гольца и нейвы из бассейна р. Охота. По мнению некоторых исследователей (Глубоковский, 1995; Черешнев, 1996), нейва и элекчанский голец относятся к арктической филогенетической группе рода Salvelinus.

(C) Волобуев В. В., Грушинец А. В., 2020
Кроме того, имеется публикация о гольцах арктического типа материкового побережья Охотского моря из других озер, расположенных в бассейнах лососевых pр. Иня, Ола, Наяхан и Яма (Гудков и др., 2003). В этой публикации авторы приводят сведения о составе озерных ихтиоценов, питании, основных морфобиологических характеристиках, окраске гольцов. В статье О. А. Радченко (2003) выполнен анализ изменчивости мтДНК трех популяций озерных гольцов из бассейнов рр. Ола, Яма и Охота. Автором сделано предположение, что в филогенезе рассмотренные популяции гольцов дивергировали от предковой линии современной мальмы.

Из всего многообразия озерных гольцов материкового побережья Охотского моря систематический статус определен лишь для гольца из бассейна р. Охота. Озерный голец из оз. Аглыкыть (его современное название - Большое Уегинское) описан как новый вид - нейва Salvelinus neiva Taranetz, 1933. Первые сведения о биологии озерного гольца из бассейна р. Охота опубликованы А. Я. Таранцом $(1933,1936)$. На основании некоторых отличий в меристических признаках (число жаберных тычинок и пилорических придатков) от проходного гольца автор выделил нейву в самостоятельный вид. Видовое название нейвы произошло от ее местного эвенского названия - няйва.

Изучение экологии, морфобиологических особенностей и паразитофауны этого гольца было продолжено в 1970-1990-е гг. (Губанов, Волобуев, 1975; Волобуев, 1976а,б, 1977). Имеют- 
ся публикации об остеологических особенностях нейвы и их сравнительном анализе с близкими видами - мальмой и кунджой (Васильева,1978; Глубоковский, 1995).

\section{МАТЕРИАЛ И МЕТОДЫ}

Материал по нейве собран в двух из семи озер, входящих в Уегинскую озерно-речную систему: в оз. Большое Уегинское и Корраль, находящихся друг от друга в пределах 1 км. Озера расположены на высоте 400 м над уровнем моря и находятся в 200 км от устья р. Охота. Посредством проток они соединены с р. Охота. Площадь зеркала Б. Уегинского озера около 2.5 км² $^{2}$, протяженность около 3.5 км. Средняя глубина 16 , максимальная 25 м (Никулин, 1970). Озеро Корраль имеет в длину около 1 км и 0.8 км в ширину. Оно мелководное, сильно заросшее макрофитами. Глубина на большей части озера колеблется от 1.5 до 3 м, максимальная глубина (10 м) отмечена в его северо-восточной части. Климат в среднем течении р. Охота резко континентальный, в течение года колебания температуры воздуха составляют -49 и $+37^{\circ} \mathrm{C}$. Температура воды в прибрежной зоне Б. Уегинского озера с мая по октябрь колеблется от 2.7 до $17.9^{\circ} \mathrm{C}$. Период открытой воды длится 4 мес. Состав ихтиофауны в оз. Корраль тот же, что и в Б. Уегинском озеpe, за исключением нерки. Однако в нем пойман 1 экз. карликового жилого кижуча (длиной 35 см и массой тела 0.7 кг). Кроме нейвы Salvelinus neiva Taranetz, в озерах обитают гольян Phoxinus phoxinus (L.), девятииглая колюшка Pungitius pungitius (L), пестроногий бычок-подкаменщик Cottus poecilopus Heckel, молодь и жилая форма нерки Oncorynchus nerka (Walbaum) и молодь кижуча Oncorhynchus kisutch (Walbaum), а также их проходные формы. Всего биологическому анализу из оз. Б. Уегинское подвергнуты 362 экз. нейвы. На питание исследовано 168 желудков. Из оз. Корраль исследован 91 экз. карликовой и 178 экз. быстрорастущей нейвы. Сбор материала проведен в 1968-1970 гг.

Кроме того, материал по озерным гольцам собран в 1976 г. из озера, расположенного на левобережной террасе в бассейне р. Вилига (приустьевой участок), впадающей в зал. Шелихова, -46 экз. и из оз. Хэл-Дэги, расположенного в верхнем течении р. Иня и входящего в одноименную озерно-речную систему на северо-востоке Хабаровского края (Волобуев, Рогатных, 1998) в 1982 г. Река Иня является крупным лососевым водоемом, впадает в Охотское море. Абсолютная высота расположения водоемов озерноречной системы Хэл-Дэги над уровнем моря около 990 м. Площадь оз. Хэл-Дэги составляет 8.75 км² $^{2}$ его средняя глубина - 20 м, максимальная -28 м. Литоральная зона озера относительно небольшая - 10-30 м. Температура поверхностного слоя воды в озере в первой-второй декадах сентября колебалась от 8.5 до $9.5^{\circ} \mathrm{C}$, прозрачность по диску Секки 6.4 м. Ихтиоцен оз. ХэлДэги представлен проходной и карликовой жилой неркой, крупной и мелкой формами гольца арктического типа Salvelinus sp., восточно-сибирским подвидом сибирского хариуса Thymallus arcticus pallasi Valenciennes и пестроногим бычкомподкаменщиком Cottus poecilopus Heckel. Всего отловлено 228 экз. гольца. Лов проводили ставными сетями и закидным неводом.

Все материалы по гольцам собраны В. В. Волобуевым и сотрудниками МагаданНИРО. Условные обозначения, принятые для описания внешней морфологии гольцов: Д - спинной плавник, $\mathrm{A}$ - анальный плавник, 11 - число чешуй в боковой линии, sp. br. - жаберные тычинки, r. br. I число жаберных лучей слева, r. br. II - число жаберных лучей справа, $\mathrm{Pc}$ - число пилорических придатков, $\mathrm{Vt}$ - число позвонков с уростилем. Римскими цифрами обозначены неветвистые лучи плавников, арабскими - ветвистые. Все материалы обработаны в соответствии со стандартными методами, применяемыми в ихтиологии (Руководство..., 1961; Правдин, 1966). Возраст всех гольцов определен по отолитам. Целью настоящей работы является обобщение и дополнение данных к имеющимся сведениям об озерных гольцах материкового побережья Охотского моря.

\section{РЕЗУЛЬТАТЫ}

Распространение. Нейва обитает в озерах Уегинской озерно-речной системы и в ряде других горных озер бассейна р. Охота и ее главного правого притока Делькю Охотская, таких как Сланцевое, Хизинджа, Кучи, Черпулай, Нек. Высота расположения некоторых озер над уровнем моря достигает 800 м. Известно (Perch, 1958), что в Европе гольцы обитают в озерах, расположенных на высоте 2658 м над уровнем моря. Все озера, в которых обитает нейва, имеют сообщение с реками, впадающими в Охотское море. Однако нейва ни в протоки, соединяющие озера с р. Охота, ни в саму р. Охота не выходит и живет оседло только в озерах. В оз. Б. Уегинское обитает быстрорастущая нейва (Волобуев, 1976а), а в соседнем о3. Корраль, кроме быстрорастущей, существует карликовая форма нейвы (Волобуев, 1977). По образу жизни нейва - придонно-пелагический вид. Взрослые особи обитают в основном в литоральной зоне озер, молодь держится в пелагиали, где находится источник ее корма - зоопланктон.

Голец озерно-речной системы Хэл-Дэги, включающей около 15 озер разной величины, имеется и в ряде других озер, например, в соседнем оз. Хадды с площадью зеркала 3.25 км² $^{2}$ 
Озерный голец этих водоемов представлен двумя симпатрическими формами, условно обозначенными нами как «белый» и «красный» гольцы. Для «красного» гольца характерно наличие карликовых самцов.

Голец из изолированного оз. Вилигинское представлен одной формой альпиноидного типа согласно проведенной дифференциации гольцов Голарктики (Савваитова, Волобуев, 1978).

Возрастная структура и рост. Нейва Б. Уегинского озера в наших сборах представлена особями от $2+$ до 14+ лет. Модальные возрастные группы составляют особи 6-7 лет (50\%).

В соседнем о3. Корраль предельный возраст быстрорастущей нейвы равен $12+$ лет. Доминирующие возрастные группы здесь также составляют 6-7-летние рыбы (40\%). Возраст карликовой нейвы колебался от 2+ до 6+ лет. Преобладающие возрастные группы у нее - 3+ и 4+ (73\%).

В уловах гольца из Вилигинского озера встречались особи от 4+ до 9+ лет. Доминирующие возрастные группы здесь представлены также 6-7-летками (64\%).

Наиболее крупная и быстрорастущая нейва обитает в Б. Уегинском озере. Здесь она достигает 65 см длины и массы тела 2.5 кг. Наиболее быстрый рост уегинской нейвы происходит с 3 до 6 лет, что, очевидно, вызвано переходом на питание в этом возрасте с планктонного типа на рыбнобентосный. Затем рост ее замедляется, что, видимо, обусловлено половым созреванием. Такая динамика роста в онтогенезе отмечена и для гольцов других популяций (Fries et al., 1895; Sprules, 1952; Perch, 1958; Nelson, 1959; Савваитова, Решетников, 1961; Quegley, 1962; Nilsson, 1963, 1965; Кохменко, 1970; Савваитова, Кохменко, 1971; Gullestad, 1973; Skreslet, 1973). В дальнейшем темп роста остается невысоким, ежегодные приросты длины колеблются от 1 до 3 см (табл. 1).

Сходная картина роста быстрорастущей нейвы наблюдается и в оз. Корраль. Более интенсивно она растет здесь до 7 лет, затем после полового созревания рост замедляется. В оз. Корраль нейва растет медленнее, чем в Б. Уегинском, что, очевидно, обусловлено худшей пищевой обеспеченностью. Максимальная длина быстрорастущей формы в этом озере составляет $47 \mathrm{~cm}$, масса -1530 г.

Карликовая нейва оз. Корраль по темпу роста значительно уступает быстрорастущей соответствующих возрастных групп (см. табл. 1), что связано с особенностями питания рыб этих группировок. Карликовая нейва достигает длины 26 см и массы 154 г. Наибольшие приросты ее длины происходят до 4 лет, после чего темп роста замедляется.

Голец Вилигинского озера достигает длины 42 см и массы 570 г. Растет он медленнее, чем быстрорастущая нейва из Б. Уегинского озера, достигает возраста 9+ лет (см. табл. 1). Предельный возраст, размеры и темп роста исследованных озерных гольцов материкового побережья Охотского моря сходны с аналогичными показателями озерных гольцов из бассейнов рр. Ола, Яма, Наяхан, дельты Лены и Камчатки (Савваитова, Решетников, 1961; Мина, 1962; Кохменко, 1970; Савваитова, Кохменко, 1971; Гудков и др., 2003).

«Белый» голец из оз. Хэл-Дэги представлен крупными рыбами длиной до 60 см и массой до 3 кг. Размеры и масса тела самцов составили в среднем 40.5 см и 0.73 кг, самок - соответственно, 35.2 и 0.48 кг. По сообщению местных рыбаков «белый» голец достигает длины 80 см и массы 6 кг. В уловах встречены особи в возрасте от

Таблица 1. Рост озерных гольцов материкового побережья Охотского моря, см

Table 1. Growth of lake chars on the the Sea of Okhotsk continental coast, cm

\begin{tabular}{|c|c|c|c|c|c|c|c|c|c|c|c|c|c|c|c|c|}
\hline \multirow{2}{*}{ Водоем, форма } & \multicolumn{15}{|c|}{ Возраст, лет } & \multirow{2}{*}{ Экз. } \\
\hline & $2+$ & $3+$ & $4+$ & $5+$ & $6+$ & $7+$ & $8+$ & $9+$ & $10+$ & $11+$ & $12+$ & $13+$ & $14+$ & $15+$ & $16+$ & \\
\hline $\begin{array}{l}\text { оз. Б. Уегинское, } \\
\text { быстрорастущая }\end{array}$ & 14.2 & 19.4 & 28.5 & 35.4 & 41.3 & 43.6 & 46.3 & 47.4 & 49.5 & 50.7 & 53.0 & 55.0 & 50.9 & - & - & 400 \\
\hline $\begin{array}{l}\text { оз. Корраль, } \\
\text { быстрорастущая }\end{array}$ & 16.3 & 22.3 & 25.7 & 31.3 & 33.7 & 36.1 & 38.1 & 41.5 & 44.6 & 46.0 & 45.6 & - & - & - & - & 178 \\
\hline $\begin{array}{l}\text { оз. Корраль, } \\
\text { карликовая }\end{array}$ & - & 18.5 & 21.4 & 23.2 & 24.6 & - & - & - & - & - & - & - & - & - & - & 91 \\
\hline $\begin{array}{l}\text { оз. Вилигинское, } \\
\text { быстрорастущая }\end{array}$ & - & - & 24.3 & 30.5 & 32.8 & 35.0 & 37.0 & 42.0 & - & - & - & - & - & - & - & 46 \\
\hline $\begin{array}{l}\text { оз. Хэл-Дэги, } \\
\text { «красный» голец }\end{array}$ & - & 14.5 & 20.0 & 23.1 & 25.2 & 26.6 & 27.5 & 28.1 & 28.6 & 30.8 & 30.9 & - & - & - & - & 202 \\
\hline $\begin{array}{l}\text { о3. Хэл-Дэги, } \\
\text { «белый» голец }\end{array}$ & - & 18.5 & 20.9 & 25.3 & 31.1 & 34.8 & 37.4 & 39.5 & 41.0 & 42.1 & 43.0 & 43.1 & 44.6 & - & 52.2 & 26 \\
\hline оз. Б. Мак-Мак* & - & 19.0 & 20.1 & 24.4 & 27.2 & 29.2 & 29.5 & 30.6 & 29.7 & 32.0 & 31.2 & - & - & - & - & 276 \\
\hline
\end{tabular}

*Данные по гольцу оз. Б. Мак-Мак приведены по работе (Гудков и др., 2003). 
$3+$ до 16+ лет (см. табл. 1), преобладали (до 60\%) самки.

«Красный» голец более мелкий, его размеры не превышали 35 см. В уловах преобладали самцы (до $82 \%$ ). Средний размер самцов составил 28.1 см, масса тела -0.20 кг, самок -24.6 и 0.13 кг соответственно. «Красный» голец по отношению к «белому» характеризуется более замедленным темпом роста. Возраст колебался от 3+ до 12+ лет (см. табл. 1).

Вместе с «красным» гольцом в литоральной зоне встречаются его карликовые самцы. Их возраст варьировал от 4+ до 8+ лет. Они характеризуются ювенильной организацией тела, на боках имеются 12-13 parr-marks. Средние показатели длины и массы тела составили 18.3 см и 58 г. Длина тела варьировала от 16.2 до 20.8 см.

Как молодь, так и половозрелые рыбы обеих форм хорошо различаются фенотипически.

Как правило, озерные гольцы отличаются от проходных замедленным ростом. Эта особенность роста озерных гольцов отмечена рядом авторов для различных географических районов (Борисов, 1932; Sprules, 1952; Лобовикова, 1959; Савваитова, 1961, 1976; Мина, 1962; Gullestad, 1973 и др.).

Сравнение по темпу роста проходных и озерных гольцов из бассейнов рр. Вилига и Охота в зонах симпатрии показало, что рост проходного гольца значительно превышает рост жилых озерных гольцов.

Размножение. В оз. Б. Уегинское нейва созревает в 5-7 лет. Наименьший возраст половозрелых самок составляет 4+ при длине 30 34 см, самцов - 6+ и 40-43 см соответственно. В оз. Корраль самцы и самки быстрорастущей нейвы впервые созревают несколько позднее - на седьмом году жизни при длине 35-37 см. Самцы карликовой нейвы созревают на третьем году при длине 16 см, самки - на четвертом при длине 19 см.

В оз. Вилигинское созревание самок наступает на шестом году жизни при достижении длины 30 $32 \mathrm{~cm}$, самцов - на восьмом году при длине $37 \mathrm{~cm}$.

Размножение нейвы происходит в озерах. Нерест протекает в сентябре - ноябре, основная масса рыб нерестится в октябре, отдельные особи в брачном наряде с текучими половыми продуктами встречаются в уловах в течение всего лета. Нерест нейвы происходит в литоральной зоне озера на галечном грунте на глубине 2-4 м. Обычно нерестилища нейвы совпадают с нерестилищами нерки, что косвенно свидетельствует о том, что нейва при выборе участков для размножения предпочитает выходы грунтовых или таликовых вод. Нерка в Б. Уегинском озере размножается в литоральной зоне на выходах грунтовых вод (Волобуев, Рогатных, 1997).
Непосредственно сам нерестовый акт нейвы нами не наблюдался, но в районе нерестилищ нерки в октябре через лед были хорошо видны пары гольцов в ярком брачном наряде красноватооранжевого окраса, находившиеся около нерестовых гнезд. Кроме того, в конце октября нейва с текучими половыми продуктами хорошо ловится подо льдом в районе нерестилищ. Температура воды в период интенсивного нереста нейвы в Б. Уегинском озере колебалась от 4.8 до $2.6^{\circ} \mathrm{C}$ (Никулин, 1975).

В оз. Корраль быстрорастущая и карликовая группировки нейвы образуют единый нерестовый пул и имеют общий генофонд. Производители нейвы обеих форм нерестятся совместно в одни и те же сроки (сентябрь-октябрь) на одних и тех же нерестилищах. Места нереста - прибрежные участки озера, свободные от макрофитов. Нерест протекал при температуре $3.4-8.0^{\circ} \mathrm{C}$.

Нейва, так же как и проходной голец, размножается в течение жизни несколько раз, но нерест у нее не ежегодный. Пропуск нереста отмечен нами для ее быстрорастущей и карликовой форм. В июле-августе в оз. Б. Уегинское и Корраль ловились особи с явными следами нереста в предыдущем году. Об этом свидетельствовали наличие в полости тела и на яйценосных пластинах остаточных икринок предыдущей генерации и низкая упитанность рыб. Морфология яичников и физиологическое состояние гольцов указывали на то, что их половые железы не смогут дозреть в текущем году. Эти рыбы пропускали нерест в данном сезоне. Период подготовки к следующему нересту у них растянут и, очевидно, составляет около 2 лет. Пропуск нерестовых сезонов у озерных гольцов, обитающих в водоемах Арктики и Субарктики, - широко распространенное явление, отмечаемое многими исследователями (Miller, Kennedy, 1948; Sprules, 1952; Лобовикова, 1959; Nielson, 1961; Gullestad, 1973; Савваитова, 1976; и др.). Причиной неежегодного размножения гольцов в высоких широтах, очевидно, является короткий период вегетации и обусловленная этим невозможность аккумуляции рыбами необходимых энергетических веществ для ежегодного нереста.

Абсолютная плодовитость нейвы невелика. Например, у нейвы Б. Уегинского озера она колеблется от 274 до 1840 и в среднем составляет 767 икр. Абсолютная плодовитость быстрорастущей нейвы о3. Корраль - 428-1531, в среднем 712 икр. Самой низкой плодовитостью характеризуется карликовая нейва - 94-193, в среднем 124 икр. Невысокую плодовитость имеет и вилигинский озерный голец - 329-612, в среднем 445 икр. Во всех популяциях озерного гольца абсолютная плодовитость увеличивается с возрастом рыб (табл. 2). 
Таблица 2. Плодовитость озерных гольцов материкового побережья Охотского моря

Table 2. Fecundity of lake chars from the Sea of Okhotsk continental coast

\begin{tabular}{|c|c|c|c|c|c|c|c|c|c|}
\hline \multirow{2}{*}{$\begin{array}{c}\text { Водоем, } \\
\text { форма }\end{array}$} & \multirow{2}{*}{ Показатель } & \multicolumn{7}{|c|}{ Возраст, лет } & \multirow{2}{*}{ Средняя } \\
\hline & & $3+$ & $4+$ & $5+$ & $6+$ & $7+$ & $8+$ & $9+$ & \\
\hline \multirow{4}{*}{ 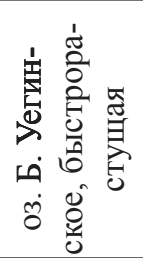 } & $\begin{array}{l}\text { Абсолютная плодови- } \\
\text { тость, икр. }\end{array}$ & - & 278 & 545 & 750 & 988 & 1628 & 1281 & 767 \\
\hline & $\begin{array}{l}\text { Относительная } \\
\text { витодо- }\end{array}$ & - & 1.00 & 1.80 & 1.87 & 1.87 & 2.19 & 1.58 & 1.83 \\
\hline & Диаметр икринок, мм & - & 3.81 & 5.38 & 5.25 & 5.25 & 5.25 & 5.35 & 5.26 \\
\hline & $\mathrm{N}$, экз. & - & 1 & 15 & 9 & 4 & 3 & 1 & 33 \\
\hline \multirow{4}{*}{ 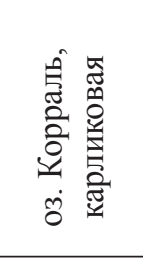 } & $\begin{array}{l}\text { Абсолютная плодови- } \\
\text { тость, икр. }\end{array}$ & 98 & 193 & 104 & - & - & - & - & 124 \\
\hline & $\begin{array}{l}\text { Относительная } \\
\text { витодос- } \\
\end{array}$ & 1.80 & 2.10 & 1.45 & - & - & - & - & 1.70 \\
\hline & Диаметр икринок, мм & 4.40 & 4.82 & 5.28 & - & - & - & - & 4.94 \\
\hline & $\mathrm{N}$, экз. & 1 & 2 & 1 & - & - & - & - & 4 \\
\hline \multirow{4}{*}{ 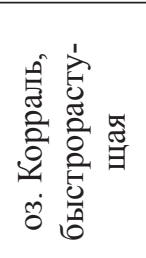 } & $\begin{array}{l}\text { Абсолютная плодови- } \\
\text { тость, икр. }\end{array}$ & - & - & - & 428 & 436 & 1531 & 722 & 712 \\
\hline & $\begin{array}{ll}\text { Относительная } & \text { плодо- } \\
\text { витость, икр./г } & \\
\end{array}$ & - & - & - & 2.08 & 1.26 & 3.73 & 1.14 & 1.91 \\
\hline & Диаметр икринок, мм & - & - & - & 5.48 & 5.45 & 5.10 & 5.85 & 5.47 \\
\hline & $\mathrm{N}$, экз. & - & - & - & 1 & 2 & 1 & 1 & 5 \\
\hline \multirow{4}{*}{ 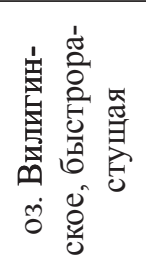 } & $\begin{array}{l}\text { Абсолютная } \\
\text { пость, икр. }\end{array}$ & - & - & 329 & 472 & 612 & - & - & 445 \\
\hline & $\begin{array}{l}\text { Относительная } \\
\text { витость, икр./г }\end{array}$ & - & - & 1.63 & 1.42 & 1.76 & - & - & 1.66 \\
\hline & Диаметр икринок, мм & - & - & 3.28 & 3.35 & 3.42 & - & - & 3.32 \\
\hline & $\mathrm{N}$, экз. & - & - & 2 & 1 & 1 & - & - & 4 \\
\hline
\end{tabular}

Относительная плодовитость озерного гольца ниже, чем у проходной формы мальмы. В уегинской популяции нейвы наблюдается некоторое увеличение относительной плодовитости с возрастом, в остальных популяциях подобной зависимости не прослеживается, что, видимо, обусловлено малой численностью зрелых самок. Интересно, что икра карликовой нейвы такая же крупная, как и у быстрорастущей формы, и почти не уступает ей по величине.

Половозрелые особи «белого» гольца оз. ХэлДэги $12+\ldots 16+$ лет с признаками готовности к нересту встречались во второй декаде сентября. «Красный» голец созревает раньше, чем «белый», - на 7-9-м годах жизни. Плодовитость его колебалась от 170 до 465, в среднем - 265 икр. Икра оранжевого цвета, диаметр икринок в среднем $4.3 \mathrm{Mм}$.

Нерест «красного» гольца происходит, повидимому, в литоральной зоне озера, так как в течение сентября численность его производителей в прибрежье озера значительно возросла. В это время вместе с «красным» гольцом на нерестилищах встречаются его карликовые самцы.

Абсолютная плодовитость нейвы и вилигинского озерного гольца приближается к показателям плодовитости гольцов из оз. Б. Леприндо (Пронин, 1967), оз. Фролиха (Мухомедиаров, 1942; Савваитова и др., 1977), бассейна р. Алазея
(Кафанова, Ширинский, 1976), но уступает плодовитости гольцов других районов (табл. 3). Повидимому, столь малая плодовитость озерных гольцов охотоморского побережья объясняется небольшими размерами самок. В связи с этим, очевидно, в популяциях осуществляется саморегуляция численности вследствие понижения уровня плодовитости.

Подобная саморегуляция численности может происходить в связи с ухудшением условий питания, обусловленным возросшей численностью популяции. Кроме того, одной из причин низкой плодовитости озерных гольцов является больший, по сравнению с проходным гольцом, размер икринок. Так, если у проходной мальмы диаметр зрелых икринок обычно не превышает 3 мм, то у озерного гольца размер дефинитивных икринок обычно более 4 мм (см. табл. 2, 3).

Популяционная плодовитость озерных гольцов довольно низкая. Так, у нейвы оз. Б. Уегинское она равна 29.4, о3. Корраль - 5.3. Невысокие показатели популяционной плодовитости озерного гольца, видимо, обусловлены низкой абсолютной плодовитостью и малым числом размножающихся самок. Очевидно, величины популяционной плодовитости озерных гольцов являются достаточными для поддержания эффективной численности популяции в сложившихся условиях. 
Таблица 3. Плодовитость озерных гольцов по ареалу

Table 3. Fecundity of lake chars by the area

\begin{tabular}{|c|c|c|c|c|}
\hline \multirow{2}{*}{ Район } & \multicolumn{2}{|c|}{ Плодовитость, икр. } & \multirow{2}{*}{$\begin{array}{l}\text { Диаметр } \\
\text { икр., мм }\end{array}$} & \multirow{2}{*}{ Автор } \\
\hline & $\lim$ & средняя & & \\
\hline $\begin{array}{l}\text { оз. Женевское (Швейца- } \\
\text { рия) }\end{array}$ & $400-2500$ & 1100 & $3-4$ & Perch, 1958 \\
\hline Озеро в Швеции & $1230-4108$ & - & $5-5,5$ & Fries et al., 1895 \\
\hline оз. Онежское & $2848-5845$ & - & - & Смирнов, 1933 \\
\hline о3. Фролиха & $360-800$ & 536 & 5.2 & Савваитова и др., 1977 \\
\hline оз. Б. Леприндо & $772-1056$ & - & $5.7-6.3$ & Пронин, 1967 \\
\hline о3. Хадыга & $1900-4200$ & 2800 & - & Амстиславский, 1974 \\
\hline Озеро в дельте Лены & $1944-6000$ & - & - & Мина, 1962 \\
\hline оз. Лабынкыр & 750 & - & - & Кириллов, 1972 \\
\hline оз. Дальнее & $685-2400$ & 2250 & 3.0 & Савваитова, 1962 \\
\hline оз. Азабачье & $1740-2048$ & - & - & Савваитова, Кохменко, 1971 \\
\hline оз. Б. Уегинское & $274-1840$ & 767 & $4.0-5.2$ & Волобуев, 1976а \\
\hline оз. Корраль & $94-1531$ & 712 & $5.4-5.8$ & Волобуев, 1977 \\
\hline оз. Элекчанские & $490-4433$ & 1956 & - & Гудков, Радченко, 2000 \\
\hline $\begin{array}{l}\text { о3. Хэл-Дэги, «красный } \\
\text { голец» }\end{array}$ & $170-465$ & 265 & 4.7 & Наши данные, 1982 \\
\hline
\end{tabular}

В уегинской и вилигинской популяциях озерных гольцов соотношение самцов и самок близко 1:1. В популяциях озерных гольцов соотношение самцов и самок может быть близким 1:1 (Савваитова, Кохменко, 1971; Савваитова, 1976), но чаще преобладали самки (Лобовикова, 1959; Пронин, 1967; Савваитова и др., 1977; Гудков, Радченко, 2000).

Карликовая нейва в оз. Корраль представлена в основном самцами - 93\%, самки встречаются редко - 7\%. Среди быстрорастущей нейвы этого озера, наоборот, наблюдается преобладание самок $-65 \%$. Возможно, что преобладание самцов среди карликовой нейвы обусловливает более низкую численность самцов быстрорастущей формы.

Питание. Питание нейвы Б. Уегинского озера исследовали с мая по октябрь включительно. Для анализа брали рыб длиной 13-57 см. В пи- тании прослеживается возрастная и сезонная изменчивость. Нейва размером до 30-35 см питается зоопланктоном. Затем, очевидно, потребление планктона становится энергетически невыгодным (Медников, 1962) и рыбы переходят на питание более крупными и калорийными объектами - рыбой, моллюсками, крупными личинками ручейников.

Молодь нейвы питается преимущественно планктонными ракообразными (Cladocera, Copepoda). Хирономиды и моллюски в рационе встречаются в незначительном количестве. Из пелагических ракообразных в желудках молоди отмечены Daphnia longiremis Sars, Bosmina obtusirostris Sars, Cyclops scutifer Sars. В количественном отношении первостепенное значение в питании молоди нейвы имели Daphnia (76\%) и Bosmina (21\%), Cyclops составили всего 1.7\% (табл. 4).

Таблица. 4. Питание молоди нейвы в Б. Уегинском озере в августе Table 4. Food of neiva fry in B. Ueginsky Lake in August

\begin{tabular}{|l|c|c|c|}
\hline \multirow{2}{*}{\multicolumn{1}{c|}{ Пищевые компоненты }} & Частота & \multicolumn{2}{c|}{ Количество организмов в одном желудке } \\
\cline { 3 - 4 } & встречаемости,\% & экз. & $\%$ \\
\hline Daphnia longiremis & 72 & 2857.7 & 76.3 \\
\hline Bosmina obtusirostris & 65 & 815.4 & 21.6 \\
\hline Cyclops scutifer & 30 & 65.4 & 1.7 \\
\hline Chironomidae nimphae & 11 & 8.2 & 0.2 \\
\hline Chironomidae pupae & 8 & 0.4 & + \\
\hline Valvata brevicula & 4 & 0.4 & + \\
\hline Spherium levinodis & 4 & 0.2 & + \\
\hline Lymnea sp. & 4 & 0.2 & + \\
\hline $\begin{array}{l}\text { Средний общий индекс наполне- } \\
\text { ния, \%оо }\end{array}$ & \multicolumn{3}{|c|}{66.08} \\
\hline
\end{tabular}

Примечание. Длина рыб 13-35 см (в среднем 27.3 см). Знак + обозначает величину менее 0.1. Исследовано 26 желудков с пищей. 
Преобладание в пище Daphnia и Bosmina наблюдается в течение всего периода нагула. У двух рыб в желудках наряду с планктонными ракообразными обнаружены моллюски Valvata brevicula Kosh., Spherium levinodis W. и молодь Lymnea sp. По-видимому, у этих рыб происходил переход с планктонного типа питания на бентосный.

Степень накормленности рыб была средней и определялась индексом наполнения, равным $66 \%$. На Камчатке C. scutifer и B. longiremis coставляют основу питания трехиглой колюшки и молоди нерки в оз. Дальнее (Марковцев, 1972), а также молоди нерки и колюшки в оз. Азабачье (Куренков, 1972; Бугаев, 1995).

В питании нейвы старших возрастных групп хорошо прослеживается смена одних пищевых объектов другими в течение сезона. Сезонная изменчивость характера питания обусловлена лабильностью кормовой базы озера. Желудки нейвы, пойманной в мае подо льдом, были пусты. В начале июня с освобождением от льда прибрежной зоны озера в питании нейвы преобладали крупные личинки ручейников Nemataulius punctatolineatus Rets, Hydatophylax nigrovittatus McL., Lymnophylus sp. (до 80\% по массе), субимаго мошек Simuliidae (до 70\%). Реже встречались личинки стрекоз, двукрылых, икра гольяна, моллюски и рыба.

После вскрытия озера в конце июня - июле значение амфибиотических насекомых в питании нейвы снижается в связи с их вылетом. В течение июля - сентября она преимущественно питалась моллюсками (63\% по массе) и рыбой (24\%) (табл. 5). Сужение спектра питания, повидимому, указывает на увеличение обеспеченности рыб пищей и соответствует периоду интенсивного нагула (Никольский, 1953). Частота встречаемости рыб с бентосным и рыбным типом питания почти одинакова -47 и $48 \%$.

В питании нейвы Б. Уегинского озера моллюски представлены шестью видами, из которых четыре имели наибольшее значение: p. Lymnea - L. auricularia lanuginosa Dyb. (46\% по мас- ce), затем p. Valvata - V. brevicula Kosh. (16\%). Anisus kamschaticus и Spherium levinodis встречались реже и в небольшом количестве. Видовой состав моллюсков в питании нейвы остается постоянным в течение сезона. Рыбы в рационе представлены девятииглой колюшкой и бычкомподкаменщиком.

Несмотря на то что в озере обитают другие виды рыб (гольян, молодь и карликовая нерка), в желудках нейвы они не обнаружены. Повидимому, она предпочитает питаться относительно малоподвижными рыбами: колюшкой и бычками-подкаменщиками. Возрастная изменчивость в питании нейвы проявляется в потреблении особями старшего возраста преимущественно крупных экземпляров моллюсков и рыб. Необходимо отметить, что накормленность нейвы моллюсками в течение сезона выше (145\%о), чем рыбами (42\%о).

Кормовая база нейвы в оз. Корраль по видовому составу идентична таковой оз. Б. Уегинское, но более бедная, что, видимо, обусловлено его меньшими глубинами, значительной гумифицированностью и влиянием резких сезонных колебаний температуры. Возможно, худшая пищевая обеспеченность рыб в оз. Корраль явилась одной из причин образования двух экологических форм нейвы - быстрорастущей и карликовой.

Молодь нейвы обеих форм в оз. Корраль нагуливается совместно и в течение 3-4 лет после рождения питается зоопланктоном. Затем часть ее переходит на питание крупными объектами - рыбой (девятииглая колюшка и бычкиподкаменщики) и бентосом (моллюски, личинки ручейников и стрекоз) и начинает быстро расти. Другая часть молоди в течение всей жизни продолжает питаться зоопланктоном, медленно растет и созревает в более раннем возрасте.

Наполнение желудков нейвы оз. Корраль в течение всего сезона открытой воды, как правило, было ниже, чем в оз. Б. Уегинское. В отличие от быстрорастущей, большая часть карлико-

Таблица 5. Общий пищевой спектр нейвы старших возрастных групп оз. Б. Уегинское в июле-августе по группам организмов

Table 5. Total food spectrum of neiva from older age groups in B. Ueginskoe Lake, in July-August, by groups of organisms

\begin{tabular}{|c|c|c|c|c|c|c|}
\hline \multirow{2}{*}{ Пищевые компоненты } & \multirow{2}{*}{$\begin{array}{c}\text { Частота } \\
\text { встречаемости, } \\
\%\end{array}$} & \multicolumn{2}{|c|}{$\begin{array}{c}\text { Среднее количество } \\
\text { организмов в одном желудке }\end{array}$} & \multicolumn{2}{|c|}{$\begin{array}{c}\text { Средняя масса организмов } \\
\text { в одном желудке }\end{array}$} & \multirow{2}{*}{$\begin{array}{c}\text { Индекс } \\
\text { наполнения } \\
\text { желудков, } \\
\% о\end{array}$} \\
\hline & & экз. & $\%$ & мГ & $\%$ & \\
\hline Dyptera imago & 3 & 0.5 & 0.3 & 81.7 & 0.7 & 1.72 \\
\hline Trichoptera larvae & 6 & 0.2 & 0.2 & 44.3 & 0.4 & 0.58 \\
\hline Odonata larvae & 10 & 0.2 & 0.2 & 3.9 & + & 0.08 \\
\hline Mollusca & 48 & 143.4 & 97.2 & 7957.0 & 63.4 & 145.65 \\
\hline Pisces & 47 & 1.9 & 1.3 & 3013.1 & 24.1 & 42.21 \\
\hline Домики ручейников & 7 & 1.2 & 0.8 & 412.7 & 3.4 & 14.97 \\
\hline Неопределенные остатки & 21 & - & - & 994.9 & 8.0 & 7.61 \\
\hline
\end{tabular}


вой нейвы (57\%) в период нереста не прекращает питаться.

Голец о3. Вилигинское в июле-августе питался рыбой (девятииглая колюшка, бычкиподкаменщики), моллюсками (Anisus sp., Valvata sp.), хирономидами, ручейниками, воздушными насекомыми. Пища обнаружена у $36 \%$ рыб. Накормленность рыб была низкой - индексы наполнения желудков колебались от 18.2 до $31.6 \%$ о. Рыбная пища встречена у $48 \%$ рыб.

У «белого» гольца оз. Хэл-Дэги преобладает хищный тип питания. Во всех просмотренных желудках обнаружены бычки-подкаменщики, изредка встречались организмы бентоса - ручейники и моллюски. Крупные особи переходят на питание «красным» гольцом. Молодь питается в основном бентосом и молодью бычка-подкаменщика. Общий средний индекс наполнения желудков 119\%о。.

В питании «красного» гольца отмечены организмы планктона и бентоса, частота их встречаемости примерно равная. Средний общий индекс наполнения желудков 65\%о. Основу питания карликовых самцов составляет зоопланктон, изредка встречается бентос. Общий индекс наполнения желудков 66\%о. Более низкие значения индексов наполнения желудков у «красного» гольца и его карликовой формы объясняются, очевидно, пониженной интенсивностью питания в нерестовый период.

Голец из Элекчанских озер характеризуется сходным характером питания: молодь питается бентосом, взрослые - девятииглой колюшкой и бычками-подкаменщиками (Гудков, Радченко, 2000).

Жилые озерные гольцы Сибири и Дальнего Востока в основном хищники. Они питаются молодью промысловых рыб, а также сорными и малопромысловыми рыбами: гольяном, бычкамиподкаменщиками, сигами, окунем и др. (Мухомедиаров, 1942; Подлесный, Лобовикова, 1953; Лобовикова, 1959; Савваитова, Решетников, 1961; Пронин, 1967; Редкозубов, Мовчан, 1974; Савваитова и др., 1977). В ряде случаев отмечено смешанное питание бентосом и рыбой (Рудакова, 1941; Мина, 1962). При отсутствии другой пищи в олиготрофных озерах голец может питаться зоопланктоном в течение всего жизненного цикла (Борисов, 1932). В озерах Полярного Урала голец питается ракообразными, моллюсками и насекомыми (Амстиславский, 1974, 1976).

Более разнообразен пищевой спектр озерной формы гольца Камчатки. В оз. Дальнее он в основном питается рыбой, поедая трех- и девятииглую колюшек и в незначительном количестве бентос (Савваитова, Решетников, 1961).

У озерно-речных гольцов оз. Азабачье наблюдается четкая дифференциация по характеру питания на гольцов-бентофагов и гольцов- хищников. Бентофаги питаются преимущественно моллюсками, хищники - молодью нерки, колюшкой и корюшкой (Кохменко, 1970; Савваитова, Кохменко, 1971). В других частях ареала характер питания озерных гольцов также довольно разнообразен.

На Аляске они питаются воздушными насекомыми, моллюсками, молодью и икрой лососей (DeLacy, Morton, 1943; Nelson, 1959). В озерах атлантического побережья Канады основная пища гольца - моллюски и корюшка (Sprules, 1952; Quegley, 1962). В озерах Скандинавии пищу гольца составляют крупные ракообразные, личинки амфибиотических насекомых, моллюски (Fries et al., 1895; Nilsson, 1963, 1965). В Швейцарии озерный голец питается зоопланктоном, моллюсками и рыбой (Perch, 1958). Кроме того, при недостаточной обеспеченности пищей озерный голец может переходить к каннибализму (DeLacy, Morton, 1943; Nilsson, 1965; Gullestad, 1973; Skreslet, 1973; Амстиславский, 1974). Характер питания озерных гольцов р. Salvelinus сходен на всем ареале и обычно определяется особенностями кормовой базы водоемов.

Озерные гольцы материкового побережья Охотского моря по характеру питания полизоофаги. Строгой специализации по какому-либо кормовому объекту у них нет, пищевой спектр разнообразен и меняется в зависимости от сезона года и наличия преобладающего корма.

Морфобиологические признаки и окраска. Уегинский озерный голец характеризуется следующими признаками: Д III-IV 9-11 (10.0); А III-IV 8-10 (9.1); 11 120-140 (128.0); sp. br. 25-35 (30.3); r. br. I 9-13 (11.3); r. br. II 9-12 (10.5); Pc 34-60 (45.7); Vt 63-68 (65.3). Наши данные согласуются с описанием нейвы, приведенным А. Я. Таранцом $(1933,1936)$, но диапазон колебаний признаков шире, что, вероятно, связано с увеличением числа исследованных рыб.

Неполовозрелые рыбы прогонистые, высота тела составляет $14-15 \%$ от длины тела по Смитту, с возрастом она увеличивается до $22 \%$. Голова у нейвы сравнительно большая (17-24\%), хвостовой стебель короткий, хвостовой плавник выемчатый. Как правило, голова имеет коническую форму (у 48\% особей) или приостренную (у 30\%), реже закругленную (у 19\%). Спинной, брюшной и анальный плавники несколько сдвинуты назад, грудные плавники удлиненные. Верхняя челюсть массивная, широкая, иногда изогнута книзу, обычно заходит за вертикаль заднего края глаза или доходит до него. У $21 \%$ рыб хорошо выражен вырост соединительной ткани на нижней челюсти и выемка между praemaxillare. У большинства рыб челюсти находятся на одном уровне, иногда верхняя челюсть нависает (у 33\%), и лишь у небольшой части рыб 
(4.8\%) вперед выдается нижняя челюсть. Половой диморфизм у нейвы проявляется по некоторым признакам внешней морфологии. Самцы в среднем длиннее самок. Длина тушки, пектовентральное и вентроанальное расстояния больше у самок. Длина головы, рыла, высота головы у затылка, максимальная высота тела, длина брюшных и грудных плавников больше у самцов. Кроме того, взрослые самцы и самки отличаются по форме головы. Наиболее четко половой диморфизм проявляется в период нереста.

Быстрорастущая нейва оз. Корраль по морфооблику не отличается от нейвы оз. Б. Уегинское.

Молодь и карликовая нейва характеризуются следующими признаками: Д III-IV 8-11 (9.3); А III-IV 8-10 (8.8); 11 125-135 (130.0); r. br. I 10-13 (12.1); r. br. II 11-13 (11.4); sp. br. 27-36 (31.2); Pc 36-62 (47.4); Vt 64-66 (64.6).

Карликовая нейва несколько отличается морфологически от молоди сходных размеров более высоким телом и головой, верхняя и нижняя челюсти у нее длиннее. По меристическим признакам между ними нет отличий. Между самцами и самками карликовой нейвы половой диморфизм проявляется только в окраске в нерестовый период.

Голец Вилигинского озера характеризуется следующими признаками: Д III-V 8-11 (9.3); А IV-V 8-9 (8.1); 11 133-142 (137.1); r. br. I 13-14 (13.0); r. br. II 11-13 (12.0); sp. br. 28-33 (30.8); Pc 31-43 (37.5); Vt 65-68 (66.6).

Как правило, это небольшие рыбы длиной 30-42 см, в среднем 32-34 см, но, по сообщению местных рыбаков-любителей, в озере встречаются гольцы до 60 см длиной и массой до 2 кг. Тело прогонистое, голова удлиненная, глаза большие, верхняя челюсть массивная, обычно заходит за вертикаль заднего края глаза. Хвостовой стебель тонкий, хвостовой плавник выемчатый. Спинной плавник размещен посередине тела, анальный несколько сдвинут к хвостовому плавнику. Небольшие различия между самцами и самками имеются в длине верхней и нижней челюстей. Первые два признака больше у самцов, последний - у самок.

«Белый» голец о3. Хэл-Дэги характеризуется следующими счетными признаками: Д III-IV 9-11 (9.5); A III-IV 8-10 (8.2); 11 127-140 (135.8); r. br. $111-13$ (11.9); r. br. 2 10-12 (10.9); sp. br. 2932 (30.1); Pc 28-48 (41.4); Vt 64-67 (65.4).

Фон тела серебристо-серый, брюхо розовое. Голова и спина темные, без рисунка. На нижней челюсти имеется выступ, на верхней - выемка. Губы бледно-оранжевые, ротовая полость серая. Верхняя челюсть и жаберные крышки золотистые. Спинной плавник темно-серый, на грудных, брюшных, анальном и хвостовом плавниках концы лучей красноватого оттенка. Первые лучи грудных, брюшных и анального плавников белые. Пятна на боках тела розовые, характерно их деление боковой линией, количество их колеблется от 24 до 48, диаметр больше или меньше зрачка. Голова большая, приостренная, верхняя челюсть массивная, задний край ее изогнут книзу. Хвостовой плавник слабовыемчатый, почти усеченный. Жаберные тычинки короткие - 34 мм. Между самцами и самками наблюдаются достоверные отличия по длине грудных плавников (у самцов они относительно длиннее).

«Красный» голец характеризуется следующими признаками: Д III-IV 9-10 (9.5); A III-IV 8-10 (8.7); 11 128-137 (134.9); r. br. 1 11-13 (12.1); r. br. 2 10-12 (11.0); sp. br. 27-35 (30.7); Pc 26-46 (37.1); Vt 64-68 (66.1).

Фон тела ярко-оранжевый или оранжевокрасный в брачном наряде и розовый или красноватый у незрелых особей. Грудные, брюшные и анальный плавники красные, спинной и хвостовой - розовые. У всех плавников, за исключением хвостового, первые лучи окрашены в белый цвет. Спина и голова серовато-стального оттенка. Ротовая полость оранжевая. У взрослых особей иногда просматриваются 12-13 «размытых» parr-marks. На боках тела имеются 10-40 темно-красных пятен, некоторые из них разделяются боковой линией. Голова небольшая, заостренная, хвостовой стебель узкий, хвостовой плавник сильно выемчатый, тело невысокое. Жаберные тычинки тоньше и длиннее, чем у «белого» гольца, $-4.5-6.0$ мм.

Голец Элекчанских озер отличается от указанных гольцов по меристическим признакам в основном числом жаберных тычинок: их у него меньше - 23-28 (Гудков, Радченко, 2000).

Озерные гольцы Исландии, Европы, Азии, Северной Америки характеризуются, как правило, большим числом жаберных тычинок и пилорических придатков (табл. 6). Но, наряду с многотычинковыми озерными гольцами, имеются и сравнительно малотычинковые популяции, например, в оз. Рейдарватн (Oliva, 1951), Лабынкыр (Кириллов, 1972); Азабачье (Савваитова, 1973), Карлук (DeLacy, Morton, 1943). С другой стороны, голец из оз. Б. Леприндо (Пронин, 1967) выделяется небольшим числом жаберных тычинок из всех популяций озерных гольцов. Значительный размах колебаний наблюдается у озерных гольцов и в числе пилорических придатков. Число жаберных тычинок у озерных гольцов по ареалу варьирует от 17 до 37, пилорических придатков - от 20 до 74, позвонков от 62 до 71.

По-видимому, столь значительные вариации по числу меристических признаков у озерных гольцов по ареалу обусловлены многообразием сочетаний различных абиотических и биотических факторов, воздействующих на их популя- 
Таблица 6. Географическая изменчивость меристических признаков озерных гольцов по ареалу Table 6. Geographical variability of lake char meristic signs by the area

\begin{tabular}{|c|c|c|c|c|c|c|}
\hline \multirow{2}{*}{ Вид } & \multirow{2}{*}{ Район } & \multicolumn{4}{|c|}{ Признаки } & \multirow{2}{*}{ Автор } \\
\hline & & 11 & sp. br. & Pc & $\mathrm{Vt}$ & \\
\hline S. alpinus & оз. Рейдарватн, Исландия & - & $23-25$ & $36-40$ & - & Oliva, 1951 \\
\hline S. alpinus & о3. Женевское & - & $21-27$ & $30-40$ & $62-65$ & Fatio, 1890 \\
\hline S. alpinus & о3. Щучье & - & $22-31$ & $25-48$ & $62-68$ & Амстиславский, 1976 \\
\hline S. taimyricus & о3. Таймыр & $119-140$ & $25-31$ & $30-49$ & $63-67$ & Михин, 1955 \\
\hline S. drjagini & оз. Мелкое & $126-136$ & $26-32$ & $39-49$ & $64-67$ & Логашев, 1940 \\
\hline S. boganidae & о3. Лама & - & $26-30$ & $40-46$ & - & Белых, 1940 \\
\hline S. a. erythrinus & оз. Леприндокан & $135-143$ & $35-37$ & $45-49$ & $64-66$ & Пронин, 1967 \\
\hline S. a. erythrinus & о3. Фролиха & $125-165$ & $27-31$ & $30-50$ & $63-69$ & Савваитова и др., 1977 \\
\hline S. jacuticus & о3. Аранастах & $124-144$ & $20-27$ & $27-47$ & $64-68$ & Борисов, 1932 \\
\hline S. alpinus & Озеро в дельте Лены & - & $19-29$ & $36-65$ & $60-65$ & Мина, 1962 \\
\hline S. czerskii & оз. Лабынкыр & $133-145$ & $22-25$ & $39-54$ & - & Кириллов, 1972 \\
\hline S. alpinus & о3. Дальнее & $118-147$ & $24-29$ & $38-61$ & $63-69$ & Савваитова, 1961 \\
\hline S. alpinus & оз. Начикинское & $127-142$ & $23-27$ & $36-65$ & $63-69$ & Савваитова, 1976 \\
\hline S. alpinus & оз. Азабачье & - & $17-25$ & $20-45$ & $62-70$ & Савваитова, 1973 \\
\hline S. neiva & о3. Уегинское & $120-140$ & $25-35$ & $34-60$ & $63-68$ & Волобуев, 1976а \\
\hline S. alpinus & о3. Хэл-Дэги & $127-140$ & $27-35$ & $26-48$ & $64-68$ & Наши данные \\
\hline S. malma & оз. Карлук, Аляска & - & $21-26$ & - & $63-67$ & Morton, 1970 \\
\hline S. alpinus & $\begin{array}{l}\text { Озеро в басс. р. Сагаваниркток, } \\
\text { Аляска }\end{array}$ & - & $24-33$ & $35-52$ & - & McCart, Craig, 1973 \\
\hline S. alpinus & Аляска & - & - & $29-74$ & $66-71$ & McPhail, 1961 \\
\hline
\end{tabular}

ции. Однако, несмотря на исключительное разнообразие озерных гольцов, у них можно выделить комплекс общих признаков, обусловленных озерным образом жизни.

В целом озерные гольцы, по сравнению с проходными, характеризуются следующими общими морфологическими особенностями: более высоким телом, спинным плавником и головой, более длинными грудными плавниками, более узким хвостовым стеблем, большим диаметром глаза, выемчатым хвостовым плавником, более широкой верхней челюстью, несколько сдвинутым к хвосту спинным и анальным плавниками, большим числом жаберных тычинок и пилорических придатков. Очевидно, это адаптационные характеристики, выработавшиеся у гольцов в результате обитания в озерных экосистемах.

Нейва заметно отличается от проходной мальмы окраской. Фон тела молоди и неполовозрелых рыб серебристый, спина серая или темная, брюхо белое, грудные, брюшные и анальный плавники розоватого цвета. На теле молоди нейвы длиной до 20-22 см имеется 9-12 parr-marks, на боках мелкие светлые пятна.

В окраске половозрелых рыб можно различить два типа. Первый, по-видимому, характерен нагуливающимся особям, пропускающим нерест, по характеру окраски они сходны с неполовозрелыми.

Рыбы второго типа окрашены ярче, это или созревающие особи, готовящиеся к нересту, или недавно отнерестившиеся и не утратившие окончательно элементы брачного наряда.

Наиболее ярко брачный наряд проявляется у самцов, у самок он выражен слабее. Тело самцов окрашивается в ярко-желтый или кирпичнокрасный цвет, ранее беловатые пятна на боках 8-10 мм в диаметре становятся малиновыми. Спина и голова чернеют, губы становятся оранжевыми, грудные, брюшные и анальный плавники приобретают карминно-красный оттенок, а их неветвящиеся лучи становятся молочно-белыми Вместе с окраской изменяется и форма тела. Большим изменениям подвергается форма тела самцов. Тело несколько уплощается, становится выше, на нижней челюсти образуется вырост соединительной ткани и выемка на верхней. Форма тела самок остается почти неизменной.

Экологические формы нейвы оз. Корраль различаются по окраске. Окраска быстрорастущей нейвы оз. Корраль почти не отличается от таковой оз. Уегинское, за исключением постоянно присутствующего у всех особей слегка золотистого фона. Быстрорастущая нейва во время нереста имеет оранжево-золотистый фон тела, темные голову и спину, ярко-красное брюхо, 20 30 крупных (5-8 мм) округлых розовых или малиновых пятен, грудные, брюшные и анальный плавники красного цвета с белыми неветвящимися лучами. Интенсивность окраски одинакова у самцов и самок.

Окраска молоди имеет общий серебристоголубой фон, на боках тела и спине хорошо выде- 
ляются 13-15 parr-marks, пятна на боках желтые или розовые, диаметром около 3 мм. Грудные, брюшные и анальный плавники красноватосерые. У быстрорастущей молоди (и в Б. Уегинском озере тоже) происходят возрастные изменения элементов окраски, сходные с «посеребрением» у смолтов лососей. При достижении 2426 см молодь из «пестряток» превращается в «серебрянок».

Карликовая нейва, как правило, четко отличается от молоди по окраске. У карликовой нейвы наблюдается полиморфизм по элементам окраски. Хорошо выделяются четыре типа окраски. Первые три характерны для самцов, последний встречается только у самок.

Первый тип. Фон тела бледно- или золотисторозовый, спина светло-коричневая, голова темная, брюхо светло-розовое. Плавники розовые. Parr-marks стального оттенка, нечеткие. Пятна на боках оранжевые или красные. Этот тип окраски самый распространенный. Его встречаемость составляет $58 \%$.

Второй тип. Рыбы ярко окрашены, имеют ярко-красное или оранжево-красное брюхо, темные голову и спину и ярко-красные грудные, брюшные и анальный плавники. Parr-marks хорошо выражены. Особи этого типа окраски встречаются реже - до $27 \%$.

Третий тип. Ювенальный тип окраски. Карликовая нейва с такой окраской не отличается от молоди быстрорастущей и попадается редко всего в $9 \%$ случаев.

Четвертый тип. Фон тела желтовато- или коричневато-серый, брюхо серовато-белое. Спина темная. Плавники темно-серые, оторочены pозовым. Parr-marks широкие, выражены слабо. Встречаемость окраски этого типа составила $6 \%$. Все рассмотренные варианты окраски встречаются у карликовой нейвы в различных размерных и возрастных группах.

Голец Вилигинского озера имеет сероватозолотистый фон тела, темную спину, розовато- оранжевое брюхо, красновато-оранжевые грудные, брюшные, анальный и хвостовой плавники. Кончики губ оранжевого цвета. Вдоль боковой линии имеются розовые пятна 3-8 мм в диаметре, иногда приближающиеся к размеру глаза. Молодь имеет серебристый фон тела и розоватосерые плавники, на теле имеются 8-14 parrmarks.

Фон тела «белого» гольца из оз. Хэл-Дэги серебристо-серый, брюхо розовое, голова и спина темные, без рисунка. Ротовая полость серого цвета. Плавники красноватого оттенка с белыми неветвистыми лучами. Пятна на боках тела розовые, характерно деление их боковой линией со сдвигом. Окраска гольцов мелкой формы («красного» гольца) - от яркооранжевой до кирпично-красной. Пятна на боках темно-красные, иногда разделяются боковой линией.

Окраска нейвы и вилигинского озерного гольца в деталях сходна с окраской камчатских гольцов из оз. Дальнее (Савваитова, 1961) и Начикинское (Савваитова, 1976), очень сходна с окраской S. drjagini (Михин, 1955; Лобовикова, 1959), озерных гольцов дельты Лены (Борисов, 1932; Мина, 1962), оз. Карлук (DeLacy, Morton, 1943). Нейва отличается по окраске от типичного S. alpinus озер Скандинавии (Fries et al., 1895), Швейцарии (Perch, 1958), Лабрадора (Backus, 1957), палии Онежского озера (Смирнов, 1933). Окраска озерных гольцов по ареалу чрезвычайно разнообразна, встречается множество цветовых вариаций, богатых различными комбинациями оттенков. Особенно изменчивым признаком окраски являются цвет, размер и число пятен на боках тела. Некоторые авторы придавали большое значение размеру пятен как одному из таксономически ценных признаков (McPhail, Lindsey, 1970; Черешнев и др., 1989), но, судя по литературным данным, сведения на этот счет самые разноречивые (табл. 7).

\section{Таблица 7. Величина пятен у озерных гольцов}

Table 7. Lake char spot sizes

\begin{tabular}{|l|l|l|}
\hline \multicolumn{1}{|c|}{ Вид, район } & \multicolumn{1}{|c|}{ Размер пятен } & \multicolumn{1}{c|}{ Автор } \\
\hline S. alpinus, Лабрадор & $1 / 3-1 / 4$ диаметра глаза & Backus, 1957 \\
\hline S. alpinus, Скандинавия & Близки к размеру зрачка & Fries et al., 1895 \\
\hline S. jacuticus, дельта Лены & Меньше зрачка & Борисов, 1932 \\
\hline S. alpinus, дельта Лены & Близки к размеру глаза & Мина, 1962 \\
\hline S. a. erythrinus, оз. Фролиха & Близки к размеру зрачка & Мухомедиаров, 1942 \\
\hline S. drjagini, оз. Таймыр & Близки к размеру глаза & Mихин, 1955 \\
\hline S. alpinus, Аляска & Близки к размеру зрачка & DeLacy, Morton, 1943 \\
\hline S. alpinus, Камчатка & Больше размера зрачка & Савваитова, 1976 \\
\hline S. пеiva, охотоморское побережье & Близки к размеру глаза & Волобуев, 1976а \\
\hline $\begin{array}{l}\text { оз. Хэл-Дэги, морфотип «белого» } \\
\text { гольца }\end{array}$ & $\begin{array}{l}\text { З9\% пятен меньше диаметра зрачка, 61\% - } \\
\text { больше его }\end{array}$ & Наши данные, 1982 \\
\hline
\end{tabular}


Таким образом, характер окраски у озерных гольцов - весьма изменчивый признак и, очевидно, малопригодный для целей таксономии.

\section{ОБСУЖДЕНИЕ И ЗАКЛЮЧЕНИЕ}

Озерные гольцы, проводящие весь жизненный цикл только в озерах, широко распространены по всему ареалу рода Salvelinus.

Нейва и гольцы из оз. Вилигинское и Хэл-Дэги имеют много общих черт биологии с озерными гольцами из других рек побережья и других частей ареала, даже очень удаленных. Они сходны с ними по размерно-весовому составу, темпу роста, продолжительности жизни, возрасту полового созревания, срокам и характеру размножения, характеру питания, окраске, внешней морфологии и другим признакам.

В то же время сходство по одним признакам не исключает расхождения озерных гольцов по другим, поскольку разнообразие условий обитания обусловливает особенности их биологии. Как правило, все озерные гольцы отличаются от проходных по характерному комплексу морфобиологических признаков. У озерных гольцов больше диаметр глаза, больше голова и, соответственно, шире верхняя челюсть, спинной, анальный и брюшные плавники несколько «сдвинуты» назад, длиннее парные и выше непарные плавники, больше число жаберных тычинок и пилорических придатков.

Очевидно, различия во внешней морфологии проходных и озерных гольцов обусловлены характером роста и различной функциональной нагрузкой на определенные органы в связи с обитанием в различных стациях и типах водоемов. Озерные гольцы растут медленнее проходных и, по сравнению с ними, характеризуются относительно большими головой, диаметром глаза, длиной парных и высотой непарных плавников, более смещенными назад спинным и анальным плавниками. В то же время различия в некоторых пропорциях тела у озерных и проходных гольцов, видимо, обусловлены «биотопической изменчивостью». Образ жизни, вероятно, способствует направленному отбору полезных для популяции признаков. Миграции озерных гольцов ограничиваются пределами озер и, в соответствии с этим, форма тела, расположение и размеры плавников у них приспособлены к передвижению на незначительные расстояния. Подтверждением этому может служить разная форма хвостового плавника у проходных и озерных гольцов. Выемчатость хвостового плавника у гольцов, населяющих небольшие озера, указывает на их небольшую миграционную активность, так как площадь хвостового плавника пропорциональна скорости движения (Алеев, 1963), т. е. лучшие пловцы, какими, без сомне- ния, являются проходные гольцы, имеют почти усеченный хвостовой плавник.

Различия между проходными и озерными гольцами по числу жаберных тычинок, очевидно, связаны с характером питания. Известно, что молодь озерных гольцов в первые годы жизни питается исключительно зоопланктоном. В связи с этим большее количество жаберных тычинок у озерных гольцов можно рассматривать как своеобразную функциональную адаптацию, направленную на усиление цедильной деятельности жаберного аппарата. Необходимость большего количества жаберных тычинок и у взрослых рыб обусловлена лабильностью кормовой базы в озерах Голарктики, сезонной сменой объектов питания и связанным с этим частым «переключением» питания с одного объекта на другой.

Число пилорических придатков является еще более изменчивым признаком. По-видимому, в среднем более высокое число их у озерных гольцов необходимо и функционально обусловлено значительным разнообразием кормовых объектов, их различной калорийностью и усвояемостью и связанной с этим разной ритмикой и особенностями ферментативно-секреторной деятельности пилорических придатков.

Примером высокой экологической пластичности гольцов рода Salvelinus, и озерных гольцов в частности, их способности к формообразованию под влиянием окружающих условий является карликовая нейва оз. Корраль. Озеро Корраль первоначально, по-видимому, было заселено обычной быстрорастущей формой нейвы. Затем под воздействием комплекса неблагоприятных для существования популяции факторов (недостаточная обеспеченность кормом, высокая численность и т. д.) из быстрорастущей нейвы вычленилась группировка карликовой тугорослой. Карликовая форма от быстрорастущей отличается меньшей продолжительностью жизни, более ранним возрастом созревания, меньшими размерами, замедленным темпом роста, характером питания, соотношением самцов и самок, элементами окраски. В то же время с быстрорастущей нейвой она имеет единый генофонд, места и сроки нереста. В данном случае ситуация сходна с описанной для карликовой формы нерки (Ricker, 1938, 1959; Rounsefell, 1958; Крохин, 1967; Никулин, 1970). Подобные совместно обитающие тугорослые и быстрорастущие формы S. alpinus известны из некоторых озер Скандинавии (Nilsson, 1965; Klementsen, Ostbye, 1967; Nilsson, Filipsson, 1971). В оз. Нордлагуна на о. Ян Майен (Skreslet, 1973) существуют репродуктивно неизолированные группировки мелкого тугорослого и крупного быстрорастущего гольца, возникшие в результате пищевой специализации. 
Следует отметить, что при наличии в озере хорошо развитой кормовой базы, например, в Б. Уегинском, где нейва имеет возможность при достижении определенных размеров переключаться с питания планктоном на питание бентосом или рыбой, карликовых особей не встречается. Недостаточность крупных кормовых объектов и вынужденное питание части рыб только планктоном в течение всего жизненного цикла, по-видимому, способствует образованию неотенических форм. Одним из факторов, стимулировавших дифференциацию и сохранение двух форм нейвы в оз. Корраль, видимо, следует считать бедность кормовой базы. Вероятно, кормовая база оз. Корраль в состоянии обеспечить быстрый рост лишь определенного количества рыб, при повышении же численности популяции сверх этого предела срабатывают генетические механизмы регуляции, определяющие появление карликовых особей, всю жизнь питающихся планктоном. Возможно, в оз. Корраль отклонение от оптимума условий обитания способствует отбору генов, определяющих развитие особей по типу карликов. О генетической предопределенности развития двух форм нейвы свидетельствуют косвенные данные.

Так, при одинаковых абиотических условиях существования и при питании одной и той же пищей (зоопланктоном) часть молоди нейвы превращается в карликов, остальные рыбы развиваются по типу быстрорастущей формы. Половозрелых рыб промежуточного размера (от 26 до 35 см) не обнаружено. Это доказывает, что, достигнув половой зрелости, карлики растут очень медленно, а затем, очевидно, погибают. Исходя из того, что обе формы нейвы являются частями единой популяции, карликовую нейву, видимо, можно рассматривать как своеобразный резервный фонд производителей, способных продуцировать потомство, относящееся к быстрорастущей форме. Таким образом, несмотря на существенные различия между карликовой и быстрорастущей нейвой, они образуют единую популяционно-генетическую систему и не исключено, что при улучшении жизненных условий отбор может пойти в обратном направлении - в сторону увеличения численности быстрорастущей нейвы до полного исчезновения карликовой.

В оз. Хэл-Дэги выявлены две группировки гольца, отличающиеся по темпу роста, признакам внешней морфологии, окраске, возрастной структуре, типу питания и соотношению полов. Однако, несмотря на ряд существующих между ними отличий, есть основание полагать, что формирование двух фенотипов гольцов произошло, по-видимому, в результате дифференциации первоначально единой популяции на тугорослую и быстрорастущую формы под давлением дизруптивного отбора. Однако изоляция между двумя симпатрическими формами гольцов в озерноречной системе Хэл-Дэги, по-видимому, неполная и между ними существует обмен генами. Об этом косвенно свидетельствует наличие в уловах рыб с промежуточным фенотипом (2.7\%) и преобладание самок в группировке «белого» гольца, а самцов - у «красного» гольца. Таким образом, несмотря на дискретность выявленных группировок, они, видимо, генетически связаны в рамках единой популяционной системы. Об этом же свидетельствует сходство меристических признаков этих двух форм.

Для всех озерных гольцов рассмотренные эколого-морфологические признаки являются общими, и, вероятно, сходная направленность их изменения в различных популяциях озерных гольцов, обитающих в разных географических районах, обусловлена параллельной внутривидовой изменчивостью (Никольский, 1969). Сходный характер изменчивости морфологических признаков у озерных гольцов, видимо, в значительной степени определяется одинаковой реакцией на своеобразные условия обитания. Экологическая пластичность гольцов и более разнообразные, чем в реках, условия существования в озерных экосистемах, наряду с бедным видовым составом ихтиоценов, способствуют тому, что гольцы могут занимать и осваивать различные экологические ниши. В результате хорошо выраженной у гольцов экологической радиации и пластичности возникают разнообразные группировки и экотипы, различающиеся по характеру питания, темпу роста, срокам и местам размножения, окраске, морфологическим признакам. Но степень различия по этим признакам в различных популяциях гольца неодинакова и отражает специфические условия водоема и особенности занимаемого биотопа.

\section{ЛИТЕРАТУРА}

Алеев Ю. Г. Функциональные основы внешнего строения рыбы. М. : Изд-во АН СССР, 1963. 384 с.

Амстиславский А. 3. Морфоэкологические особенности гольца озера Хадыга : тез. докл. VI Всесоюз. науч. симпоз. «Биологические проблемы Севера». Якутск, 1974. Вып. 2. С. 84-86.

Амстиславский A. 3. О двух формах гольца Salvelinus alpinus (L.) озера Большое Щучье (Полярный Урал) // Экология. 1976. № 2. С. 86-89.

Белых Ф. И. Озеро Лама и его рыбохозяйственное использование // Тр. НИИ поляр. земледел., животновод. и промысл. хоз-ва. Сер. Промысл. хозво. 1940. Вып. 11. С. 73-100.

Борисов П. Г. Новый вид гольца Salvelinus jacuticus n. sp. // Tp. совещания по изучению производит. сил. Сер. Якутская. 1932. Вып. 3. С. 1-47. $464 \mathrm{c}$. 
Bacuльева E. Д. Остеология нейвы (р. Salvelinus, Salmonidae, Salmoniformes) озера Корраль, бассейн p. Охоты // Вестник МГУ. Сер. биол. 1978. № 4. С. 3-10.

Волобуев B. B. О карликовой форме нейвы Salvelinus neiva (Salmoniformes, Salmonidae) из оз. Корраль (бассейн р. Охота) // Зоологический журнал. 1977. Т. 56. Вып. 3. С. 405-411.

Волобуев В. В. Об экологических группировках в популяции нейвы Salvelinus neiva Taranetz озера Корраль, бассейн р. Охоты // Лососевые рыбы (морфология, систематика и экология). Л. : Изд-во Зоол. ин-та АН СССР, 1976б. С. 15.

Волобуев B. В. Систематика и экология нейвы Salvelinus neiva Taranetz о3. Уегинского (бассейн р. Охоты) // Вопросы ихтиологии. 1976а. Т. 16. Вып. 6 (101). C. 989-999.

Волобуев B. B. Систематика, экология и структура популяций гольцов рода Salvelinus материкового побережья Охотского моря : автореф. дис. ... канд. биол. наук. М., 1978. 24 с.

Волобуев B. В., Рогатных A. Ю. Условия воспроизводства лососей рода Oncorhynchus материкового побережья Охотского моря // Вопросы ихтиологии. 1997. Т. 37, № 5. С. 612-618.

Волобуев B. В., Рогатных A. Ю. Экология и видовой состав рыб озерно-речной системы ХэлДэги (континентальное побережье Охотского моря) : Материалы науч. конф. «Биологическое разнообразие животных Сибири». Томск, 1998. С. 42-43.

Глубоковский $M . \quad K$. Эволюционная биология лососевых рыб. М. : Наука, 1995. 343 с.

Губанов Н. М., Волобуев В. В. О гельминтофауне озерного гольца рода Salvelinus из бассейна реки Охоты // Паразитические организмы Северо-Востока Азии. Владивосток : ДВНЦ АН СССР, 1975. С. 187189.

Гудков П. К., Алексеев С. С., Кириллов А. Ф. Морфоэкологические особенности жилых гольцов рода Salvelinus некоторых озер Охотско-Колымского района // Вопросы ихтиологии. 2003. Т. 43, № 5. С. 639-649.

Гудков П. К., Радченко О. А. Характеристика гольца рода Salvelinus из Элекчанских озер (северное побережье Охотского моря) - морфология, биология, генетика // Там же. 2000. Т. 40, № 5. С. 621-631.

Кафанова В. В., Ширинский А. А. К биологии гольца Черского Salvelinus czerskii Drjagin из бассейна реки Алазеи // Лососевидные рыбы (морфология, систематика и экология). Л. : Изд-во Зоол. ин-та АН CСCP, 1976. С. 45-46. $360 \mathrm{c}$.

Кириллов Ф. Н. Рыбы Якутии. М. : Наука, 1972.

Кохменко Л. В. Особенности питания гольца Salvelinus alpinus (L.) в озере Азабачьем // Изв. ТИНРО. 1970. T. 78. C.117-127.

Крохин E. М. Материалы к познанию карликовой красной Oncorhynchus nerka (Walb.) в Дальнем озере (Камчатка) // Вопросы ихтиологии. 1967. Вып. 3 (44). C. 433-445.

Куренков И. И. Гидробиологическая характеристика озера Азабачьего по материалам 19491963 гг. // Известия ТИНРО. 1972. Т. 82. С.125-134.

Лобовикова A. A. Озерный голец (палья) Salvelinus drjagini из озера Маковского (Игарский район,
Красноярский край) // Тр. Всесоюз. гидробиол. о-ва. 1959. Т. 9. С. 315-319.

Логашев M. В. Озеро Мелкое и его рыбохозяйственное использование // Тр. НИИ полярн. земледел., животновод. и промысл. хоз-ва. Сер. Промысл. хоз-во. 1940. Вып. 11. С. 7-71.

Майр Э. Принципы зоологической систематики. М. : Мир, 1971. 454 с.

Марковцеев В. Г. Питание и пищевые отношения молоди красной и трехиглой колюшки озера Дальнего // Изв. ТИНРО. 1972. Т. 82. С. 227-233.

Медников Б. М. Биологическая разнокачественность кормовых организмов как фактор, определяющий рост рыб и состав промысловых комплексов // Вопросы ихтиологии. 1962. Т. 2. Вып. 2 (23). C. 299-309.

Мина М. В. Данные по экологии и систематике озерных гольцов рода Salvelinus дельты р. Лены // Там же. С. 230-241.

Михин B. C. Рыбы озера Таймыр и Таймырской губы // Изв. ВНИОРХ. 1955. Т. 35. С. 5-43.

Мухомедиаров Ф. Б. К биолого-систематической характеристике даватчана // Тр. Вост.-Сиб. ун-та. 1942. Т. 2. Вып. 3. С. 119-126.

Никольский Г. В. О закономерностях пищевых отношений у пресноводных рыб // Очерки по общим вопросам ихтиологии. М. ; Л. : Изд-во АН СССР, 1953. C. 261-281.

Никольский Г. В. О параллельной внутривидовой изменчивости у рыб // Вопросы ихтиологии. 1969. Т. 9. Вып. 1 (54). С. 7-13.

Никулин О. А. Воспроизводство красной Oпсоrhynchus nerka (Walb.) в бассейне р. Охоты // Tp. ВНИРО. 1975. Т. 106. С. 97-105.

Никулин $O$. $A$. О связи между снижением абсолютной численности красной Oncorhynchus ner$k a$ (Walb.) и увеличением относительной численности карликов среди нагуливающейся молоди в озере Уегинском (Охотский район) // Известия ТИНРО. 1970. T. 71. С. 205-217.

Подлесный А. В., Лобовикова А. А. Палья (Salvelinus) Таймырского озера // Тр. Иркут. гос. ун-та. Cер. биол. 1953. Т. 7. Вып. 1-2. С. 98-115.

Правдин И. Ф. Руководство по изучению рыб. М. : Пищ. пром-сть, 1966. 376 с.

Пронин Н. М. О биологии даватчана и восточносибирского сига Куандо-Чарского водораздела. Иркутск : Вост.-Сиб. кн. изд-во, 1967. Ч. 1. С. 59-68. (Уч. зап. Иркут. пед. ин-та. Сер. биол. ; вып. 24).

Радченко О. А. Изменчивость митохондриальной ДНК в популяциях озерных гольцов рода Salvelinus Дальнего Востока и Сибири // Вопросы ихтиологии. 2003. Т. 43, № 4. С. 553-561.

Редкозубов И. Ю., Мовчан В. А. К изучению даватчана Salvelinus alpinus erythrinus (Georgi) 03. Фролиха // Там же. 1974. Т. 14. Вып. 2 (85). С. 330 332.

Рудакова B. А. Гольцы (gen. Salvelinus) бассейна Гыданского залива // Тр. НИИ полярн. земледел., животновод. и промысл. хоз-ва. Сер. Промысл. хозво. 1941. Т.15. С.131-136.

Руководство по изучению питания рыб в естественных условиях. М. : Изд-во АН СССР, 1961. 262 c. 
Савваитова K. A. Арктические гольцы. М. : Агропромиздат, 1989. 223 с.

Савваитова К. А., Максимов В. А., Медведева Е. Д. Голец Salvelinus alpinus (L.) (Salmonidae, Salmoniformes) водоемов острова Беринга (Командорские острова) // Зоологический журнал. 1977. Т. 54. Вып. 12. С. 1847-1860.

Савваитова K. А. Гольцы Камчатки - род Salvelinus (систематика и экология) : автореф. дис. ... канд. биол. наук. М., 1962. $186 \mathrm{c.}$

Савваитова K. A. Гольцы (род Salvelinus) озера Начикинского (Камчатка) и некоторые проблемы систематики озерных гольцов Голарктики // Вопросы ихтиологии. 1976. Т. 16. Вып. 2 (97). С. 274-281.

Савваитова К. А., Волобуев В. В. К систематике арктических гольцов Salvelinus alpinus complex (Salmoniformes, Salmonidae) // Зоологический журнал. 1978. T. 57, № 10. C. 1534-1543.

Савваитова К. А., Кохменко Л. В. Некоторые особенности биологии симпатрических гольцов (Salvelinus alpinus L.) из бассейна оз. Азабачье // Вестник МГУ. 1971. № 3. С. 37-42.

Савваитова К. А. О внутривидовых биологических формах Salvelinus alpinus (L.) Камчатки // Вопросы ихтиологии. 1961. Т. 1. Вып. 4 (21). С. 696-706.

Савваитова К. А., Решетников Ю. С. Питание различных биологических форм гольца Salvelinus malma (Walb.) в некоторых водоемах Камчатки // Там же. 1961. Т. 1. Вып. 1 (18). С. 127-135.

Саввачтова К. А. Экология и систематика пресноводных гольцов рода Salvelinus (Nilsson) Richardson некоторых водоемов Камчатки // Там же. 1973. Т. 13. Вып. 1 (78). С. 68-78.

Смирнов A. Ф. Палья Онежского озера. Биология, промысел, разведение // Рыбное хозяйство Карелии. 1933. Вып. 2. С. 110-127.

Таранеи А. Я. О некоторых пресноводных рыбах из Дальневосточного края // ДАН СССР. Нов. сер. 1933. Вып. 2. С. 83-86.

Таранец А. Я. Пресноводные рыбы бассейна северо-западной части Японского моря // Тр. Зоол. инта АН СССР. 1936. Т. 4. Вып. 2. С. 483-537.

Черешнев И. А. Биологическое разнообразие пресноводной ихтиофауны Северо-Востока России. Владивосток : Дальнаука, 1996. 197 с.

Черешнев И. А., Скопеи М. Б., Гудков П. К. Новый вид гольца Salvelinus levanidovi sp. nov. из бассейна Охотского моря // Вопросы ихтиологии. 1989. Т. 29. Вып. 1. C. 68-84.

Backus R. H. The fishes of Labrador // Bull. Amer. Muc. Nat. Hist. 1957. Vol. 113, No. 4. P. 273-338.

DeLacy A. C., Morton W. M. Taxonomy and habits of the chars, Salvelinus malma and Salvelinus alpinus of the Karluk drainage system // Trans. Amer. Fish. Soc. 1943. No. 72. P. 79-91.

Fatio $V$. Fauna les vertebres de la Suisse. Histoire naturelle les Poissons. 1890. 567 p.

Fries B., Ekstrom C. U., Sundevall C. A history of Skandinavian fishes. Part III. Stokholm, 1895. P.1-713.

Frost W. E. Breeding habits of Windermere charr Salvelinus willuhghbii (Gunter) and their bearing on speciation of these fish // Proc. Roy. Soc. B. 1965. Vol. 163. P. 232-284.

Поступила в редакциюю 22.10.2018 г.

Поступила после доработки 28.10.2018 г.
Gullestad N. On the biology of Char (Salmo alpinus L.) in Svalbard. I. Migratory and non-migratory char in Revattnet, Spitsbergen // Arb. Norsk. polarinst. 1973. P. $125-140$.

Klementsen A., Ostbye E. Observations on age, condition and food of char Salvelinus alpinus from Finsevatn, C. Norway // Fauna. 1967. Vol. 20. P. 183-188.

McCart P. Y., Craig P. Life history of two isolated populations of Arctic char (Salvelinus alpinus) in springfed tributaries of the Canning River, Alaska // J. Fish. Res. Board Canada. 1973. Vol. 30, No. 8. P. 1215-1220.

McPhail J. D. A systematic study of the Salvelinus alpinus complex in North America // Ibid. 1961. Vol. 18, No. 5. P. 793-816.

McPhail J. D., Lindsey C. C. Freshwater fishes of northwestern Canada and Alaska // Ibid. 1970. No. 173. P. 1-381.

Miller R. B., Kennedy W. A. Observation on the lake trout of Great Bear Lake // Ibid. 1948. Vol. 7, No. 7. P. 176-189.

Morton $W$. M. On the validity of all subspecific descriptions of North America Salvelinus malma (Walbaum) // Copeia. 1970. No. 3. P. 581-587.

Nelson P. R. Effect of fertilizing Bare Lake, Alaska, on growth and production of red salmon (Oncorhynchus nerka) // Fish. Bull. Fish. Wildlife Serv. U. S. Inter. 1959. Vol. 60, No. 159. P. 59-86.

Nielson J. Age and growth of the fresh-water stage of anadromous char, Salvelinus alpinus L. // Contribution to the biology of the Salmonidae in Greenland. I-IV. 1961. Vol. 159, No. 8. P. 1-76.

Nilsson N. A., Filipsson $O$. Characteristics of two discrete populations of Arctic char Salvelinus alpinus L. in a north Swedish lake // Rep. Inst. Freshw. Res. Drottningholm. 1971. Vol. 51. P. 90-108.

Nilsson N. A. Food segregation between Salmonid species in North Sweden // Inst. Freshw. Res. Rep. Drottningholm. 1965. No. 46. P. 58-78.

Nilsson N. A. Interaction between trout and char in Scandinavia // Trans. Americ. Fish. Soc. 1963. Vol. 92, No. 3. P. 276-285.

Oliva O. Description of Salvelinus alpinus (Linnaeus) from Iceland // Copeia. 1951. No. 1. P. 91-92.

Perch G. La journee dun omble chevalier // Naturalia. 1958. No. 60. P. 37-44.

Quigley J. J. Landlocked Arctic char in Newfoundland // Dep. Fish. Can. 1962. Vol. 15, No. 3. P. 17.

Ricker $W$. E. Additional observations concerning residual sockeye and kokanee (Oncorhynchus nerka) // J. Fish. Res. Board Canada. 1959. Vol. 16, No. 6. P. $897-$ 902.

Ricker W. E. "Residual" and kokanee salmon in Cultus Lake // Ibid. 1938. Vol. 4. P. 192-217.

Rounsefell G. A. Anadromy in American Salmonidae // Fish. Bull. Fish Wildl. Serv. 1958. Vol. 58. P. 171185.

Skreslet S. Group segregation in landlocked Arctic char, Salvelinus alpinus (L.), of Jan Mayen Island, in relation to the char problem // Astarte. 1973. Vol. 6, No. 2. P. 55-58.

Sprules W. M. The Arctic char of the west coast of Hudson Bay // J. Fish. Res. Board Canada. 1952. Vol. 9, No. 1. P. 1-15. 


\title{
LAKE CHARS (SALVELINUS, SALMONIDAE) OF THE CONTINENTAL COAST OF THE SEA OF OKHOTSK
}

\author{
V. V. Volobuev, A. V. Grushinets
}

\author{
Magadan Research Institute of Fisheries and Oceanography, Magadan
}

\begin{abstract}
Data on distribution, migrations, reproduction, food, age, and growth of landlocked char populations from lakes of the continental coast of the Sea of Okhotsk are provided. The morphobiological characteristics of two forms of a lake char neiva (fast-growing and dwarfish) is given. Data on lake char populations from other reservoirs are presented.
\end{abstract}

\section{Keywords: distribution, migrations, food, age and growth, lake char.}

\section{REFERENCE}

Aleyev, Yu. G., 1963, Functional Basis of the External Structure of the Fish, Moscow, AS USSR [In Russian].

Amstislavsky, A. Z., 1974, Morpho-Ecological Features of the Khadyga Lake Char, Abstr. VI All-Union Scientific Symp. "Biological Problems of North”, Yakutsk, Iss. 2, 84-86 [In Russian].

Amstislavsky, A. Z., 1976, On Two Forms of Char Salvelinus alpinus (L.) of the Great Shchuchye Lake (Polar Urals), Russian Journal of Ecology, 2, 86-89 [In Russian].

Backus, R. H., 1957, The Fishes of Labrador, Bull. Amer. Muc. Nat. Hist., 113, 4, 273-338.

Belykh, F. I., 1940, Lama Lake and Its Fishery Use, Trudy Instituta Polarnogo Zemledeliya, Zhivotnovodstva $i$ Promyslovogo Khozyaystva, Ser. Promyslovoye Khozyaystvo, 11, 73-100 [In Russian].

Borisov, P. G., 1932, A New Species of Salvelinus jacuticus n. sp., Trudy Soveshchaniya po Izucheniyu Proizvoditel'nykh Sil, Ser. Yakutskaya, 3, 1-47 [In Russian].

Bugaev, V. F., 1995, Asian Sockeye, Moscow, Kolos [In Russian].

Chereshnev, I. A., 1996, Biological Diversity of Freshwater Ichthyofauna in the North-East of Russia, Vladivostok, Dalnauka [In Russian].

Chereshnev, I. A.; Skopets, M. B.; Gudkov, P. K., 1989, New Species of Char Salvelinus levanidovi sp. nov. from the Sea of Okhotsk Basin, Journal of Ichthyology, 29, 1, 68-84 [In Russian].

DeLacy, A. C.; Morton, W. M., 1943, Taxonomy and Habits of the Chars, Salvelinus malma and Salvelinus alpinus of the Karluk Drainage System, Trans. Amer. Fish. Soc., 72, 79-91.

Fatio, V., 1890, Fauna Les Vertebres de la Suisse, Histoire Naturelle Les Poissons.

Fries, B.; Ekstrom, C. U.; Sundevall, C., 1895, A History of Skandinavian Fishes, Part III, Stokholm, 1-713.

Frost, W. E., 1965, Breeding Habits of Windermere Char Salvelinus willuhghbii (Gunter) and Their Bearing on Speciation of These Fish, Proc. Roy. Soc. B., 163, 232-284.

Glubokovsky, M. K., 1995, Evolutionary Biology of Salmon Fishes, Moscow, Nauka [In Russian].

Gubanov, N. M.; Volobuev, V. V., 1975, On the Helminth Fauna of the Lake Char of the Genus Salvelinus from the Okhota River Basin, Parasitic Organisms of Northeast Asia, Vladivostok, 187-189 [In Russian].
Gudkov, P. K.; Alekseev, S. S.; Kirillov, A. F., 2003, Morphoecological Features of Landlocked Chars of the Genus Salvelinus of Some Lakes in the Okhotsk-Kolyma Region, Journal of Ichthyology, 43, 5, 639-649 [In Russian].

Gudkov, P. K.; Radchenko O. A., 2000, Characteristic of the Salvelinus Genus from the Elekchansky Lakes (Northern Coast of the Sea of Okhotsk) - Morphology, Biology, Genetics, Ibid., 40, 5, 621-631 [In Russian].

Guide to the Study of Fish Nutrition in Natural Conditions, 1961, Moscow, AS USSR [In Russian].

Gullestad, N., 1973, On the Biology of Char (Salmo alpinus L.) in Svalbard. I. Migratory and Non-Migratory Char in Revattnet, Spitsbergen, Arb. Norsk. Polarinst., 125-140.

Kafanova, V. V.; Shirinsky, A. A., 1976, To the Biology of Chersky's Charr Salvelinus czerskii Drjagin from the Alazey River Basin, Sb. Salmonid Fish (Morphology, Systematics and Ecology), Publishing House Zool. Institute of the USSR Academy of Sciences, 45-46 [In Russian].

Kirillov, F. N., 1972, Fishes of Yakutia. Moscow, Nauka [In Russian].

Klementsen, A.; Ostbye, E., 1967, Observations on Age, Condition and Food of Char Salvelinus alpinus from Finsevatn, C. Norway, Fauna, 20, 183-188.

Kohmenko, L. V., 1970, Feeding Habits of Salvelinus alpinus (L.) in Lake Azabachye, Izvestiya TINRO, 78, 117-127 [In Russian].

Krokhin, E. M., 1967, Materials for the Knowledge of Dwarf Sockeye Salmon Oncorhynchus nerka (Walb.) in the Far Lake (Kamchatka), Journal of Ichthyology, 3, 44, 433-445 [In Russian].

Kurenkov, I. I., 1972, Hydrobiological Characteristics of Lake Azabachye Based on Materials from 1949-1963, Izvestiya TINRO, 82, 125-134 [In Russian].

Lobovikova, A. A., 1959, Lake Char (Palya) Salvelinus drjagini from Lake Makovsky (Igarka District, Krasnoyarsk Krai ), Trudy Vsesoyuznogo Ghidrobiologicheskogo Obshchestva, 9, 315-319 [In Russian].

Logashev, M. V., 1940, Small Lake and Its Use in Fishery, Trudy In-ta Polarnogo Zemledeliya, Zhivotnovodstva i Promyslovogo Khozyaystva, 11, 7-71 [In Russian]. 
Markovtsev, V. G., 1972, Nourishment and Food Relationships of Juvenile Sockeye Salmon and Three-Needle Stickleback in Lake Dal'neye, Izvestiya TINRO, 82, 227233 [In Russian].

Mayr, E., 1971, Principles of Zoological Systematics, Moscow, Mir [In Russian].

McCart, P. Y.; Craig, P., 1973, Life History of Two Isolated Populations of Arctic Char (Salvelinus alpinus) in Springfed Tributaries of the Canning River, Alaska, J. Fish. Res. Board Canada, 30, 8, 1215-1220.

McPhail, J. D., 1961, A Systematic Study of the Salvelinus alpinus Complex in North America, Ibid., 18, 5, 793-816.

McPhail, J. D.; Lindsey, C. C., 1970, Freshwater Fishes of Northwestern Canada and Alaska, Ibid., 173, $1-381$.

Mednikov, B. M., 1962, Biologically Different Qualities of Food Organisms as a Factor Determining the Fish Growth and the Fishing Complex Compositions, Journal of Ichthyology, 2, Iss. 2 (23), 299-309 [In Russian].

Mikhin, V. S., 1955, Fish of Lake Taimyr and the Taimyr Bay, Izvestiya VNIOROKH, 35, 5-43 [In Russian].

Miller, R. B.; Kennedy, W.A., 1948, Observation on the Lake Trout of Great Bear Lake, Ibid., 7, 7, 176189.

Mina, M. V., 1962, Data on the Ecology and Systematics of Lake Chars of the Genus Salvelinus of the Lena River Delta, Journal of Ichthyology, 2, Iss. 2 (23), 230241 [In Russian].

Morton, W. M., 1970, On the Validity of All Subspecific Descriptions of North America Salvelinus malma (Walbaum), Copeia, 3, 581-587.

Mukhomediarov, F. B., 1942, To Biological and Systematic Characteristic of the Frolikh Char, Trudy Vostochno-Sibirskogo Universiteta, 2, 3, 119-126 [In Russian].

Nelson, P. R., 1959, Effect of Fertilizing Bare Lake, Alaska, on Growth and Production of Red Salmon (Oncorhynchus nerka), Fish. Bull. Fish. Wildlife Serv. U. S. Inter., 60, 159, 59-86.

Nielson, J., 1961, Age and Growth of the Fresh-Water Stage of Anadromous Char, Salvelinus alpinus L., Contribution to the Biology of the Salmonidae in Greenland. I-IV, 159, 8, 1-76.

Nikolsky, G. V., 1953, On Regularities in Food Relationships of Freshwater Fish, Essays on the General Issues of Ichthyology, Moscow, Leningrad, AS USSR, 261281 [In Russian].

Nikolsky, G. V., 1969, On the Parallel Intraspecific Variability in Fish, Journal of Ichthyology, 9, Iss. 1 (54), 7-13 [In Russian].

Nikulin, O.A., 1970, On the Relationship between the Decrease in the Absolute Number of Sockeye Salmon Oncorhynchus nerka (Walb.) and the Increase in the Relative Number of Dwarfs among the Fattening Fry in Lake Ueginskoye (Okhotsk Region), Izvestiya TINRO, 71, 205217 [In Russian].

Nikulin, O. A., 1975, Reproduction of the Sockeye Salmon Oncorhynchus nerka (Walb.) in the Basin of the Okhota River, Trudy VNIRO, 106, 97-105 [In Russian].

Nilsson, N. A., 1963, Interaction between Trout and Char in Scandinavia, Trans. Americ. Fish. Soc., 92, 3, 276-285.
Nilsson, N. A., 1965, Food Segregation between Salmonid Species in North Sweden, Inst. Freshw. Res. Rep. Drottningholm, 46, 58-78.

Nilsson, N. A.; Filipsson, O., 1971, Characteristics of Two Discrete Populations of Arctic Char Salvelinus alpinus L. in a North Swedish Lake, Rep. Inst. Freshw. Res. Drottningholm, 51, 90-108.

Oliva, O., 1951, Description of Salvelinus alpinus (Linnaeus) from Iceland, Copeia, 1, 91-92.

Perch, G., 1958, La Journee Dun Omble Chevalier, Naturalia, 60, 37-44.

Podlesny, A. V.; Lobovikova, A. A., 1953, Lake Char (Salvelinus) of Lake Taimyrskoye, Trudy Irkutskogo Gosudarstvennogo Universiteta, Ser. Biol., 7, 1-2, 98-115 [In Russian].

Pravdin, I. F., 1966, Guide to the Study of Fish, Moscow, Pishchevaya Promyshlennost' [In Russian].

Pronin, N. M., 1967, On the Biology of the Frolikh Char and the East Siberian Whitefish of the Kuando-Chara Watershed, Uchyoniye Zapiski Irkutskogo Pedagogicheskogo Instituta, Ser. Biol., Irkutsk, Vostochno-Sibirskoye Knizhnoye Izd-vo, 24, Part 1, 59-68 [In Russian].

Quigley, J. J., 1962, Landlocked Arctic Char in Newfoundland, Dep. Fish. Can., 15, 3, 17.

Radchenko, O. A., 2003, Variability of Mitochondrial DNA in Populations of Lake Chars of the Genus Salvelinus of the Far East and Siberia, Journal of Ichthyology, 43, 4, 553-561 [In Russian].

Redkozubov, I. Yu.; Movchan, V. A., 1974, To the Study of the Frolikh Char Salvelinus alpinus erythrinus (Georgi) Lake Frolikh, Ibid., 14, Iss. 2 (85), 330-332 [In Russian].

Ricker, W. E., 1938, "Residual" and Kokanee Salmon in Cultus Lake, J. Fish. Res. Board Canada, 4, 192 217.

Ricker, W. E., 1959, Additional Observations Concerning Residual Sockeye and Kokanee (Oncorhynchus nerka), Ibid., 16, 6, 897-902.

Rounsefell, G. A., 1958, Anadromy in American Salmonidae, Fish. Bull. Fish Wildl. Serv., 58, 171-185.

Rudakova, V. A., 1941, Chars (gen. Salvelinus) of the Gydan Bay Basin, Trudy In-ta Polarnogo Zemledeliya, Zhivotnovodstva i Promyslovogo Khozyaystva, Ser. Promyslovoye Khozyaystvo, 15, 131-136 [In Russian].

Savvaitova, K. A., 1961, On the Intraspecific Biological Forms of Salvelinus alpinus (L.) in Kamchatka, Journal of Ichthyology, 1, Iss. 4 (21), 696-706 [In Russian].

Savvaitova, K. A., 1962, Chars of Kamchatka-Genus Salvelinus (Systematics and Ecology), Moscow, Moscow State University [In Russian].

Savvaitova, K. A., 1973, Ecology and Systematics of Freshwater Chars of the Genus Salvelinus (Nilsson) Richardson in Some Water Basins of Kamchatka, Journal of Ichthyology, 13, Iss. 1 (78), 68-78 [In Russian].

Savvaitova, K. A., 1976. Chars Genus Salvelinus of Lake Nachikinskoye (Kamchatka) and Some Problems of Systematics of the Lake Chars of the Arctic, Ibid., 16, Iss. 2 (97), 274-282 [In Russian].

Savvaitova, K. A., 1989, Arctic Chars, Moscow, Agropromizdat [In Russian].

Savvaitova, K. A.; Kohmenko, L. V.,1971, Some Features of the Biology of Sympatric Chars (Salvelinus al- 